Review

\title{
How Can Local Governance Systems Strengthen Community Resilience? A Social-Ecological Systems Approach
}

\author{
Elizabeth Carabine * and Emily Wilkinson \\ Overseas Development Institute, London, SE1 8NJ, UK; E-Mails: e.carabine@odi.org.uk (E.C.), e.wilkinson@odi.org.uk (E.W.) \\ * Corresponding author
}

Submitted: 1 September 2016 | Accepted: 8 November 2016 | Published: 28 December 2016

\begin{abstract}
At their core, donor-funded climate and disaster resilience programmes provide goods and services to help build assets and minimise the impact of shocks and stresses on people's lives and livelihoods. Little is known, however, about the way local risk governance systems and the broader institutional arrangements, in which they are embedded, mediate people's access to these services and therefore lead to improved resilience. Drawing on Social-Ecological Systems theory, we explore those characteristics of risk governance systems believed to be more favourable for building resilience at the community level in different developing country contexts. These include: diversity; polycentricism and connectivity; decentralisation and flexibility; participation and community engagement; and, learning and innovation. This review paper proposes a conceptual framework and assesses the evidence linking risk governance and access to the services needed to build resilient outcomes, drawing particularly on evidence from the Sahel and Horn of Africa. In doing so, we can start to understand where the entry points might be for strengthening resilience and the conditions needed for community-level initiatives to be brought to scale from the bottom up.
\end{abstract}

\section{Keywords}

informal institutions; local risk governance; resilience; social-ecological systems; sub-Saharan Africa

\section{Issue}

This review is part of the issue "Disaster Policies and Governance: Promoting Community Resilience", edited by Naim Kapucu (University of Central Florida, USA) and Abdul-Akeem Sadiq (Indiana University-Purdue University Indianapolis, USA).

(C) 2016 by the authors; licensee Cogitatio (Lisbon, Portugal). This article is licensed under a Creative Commons Attribution 4.0 International License (CC BY).

\section{Introduction}

Risk governance refers to both the institutional arrangements and policy processes that shape risk reduction and management approaches (Renn, Ortleb, Benighaus, $\&$ Benighaus, 2011). Until recently, most formal risk governance systems were centralised and response-focused, based on chains of command (Britton, 2001). These were disconnected from local, informal efforts to manage everyday risk (van Voorst, Wisner, Hellman, \& Nooteboom, 2015). Increasingly, decision-makers are recognising that multi-level governance is required to manage the range of risks faced by communities in developing countries (Pahl-Wostl, 2009). These include climate change and disasters, conflict, environmental degradation, land use change, food insecurity and human migration and displacement, as well as interacting effects (Intergovernmental Panel on Climate Change [IPCC], 2014). In particular, strengthening of risk governance at the local level, both in terms of decision-making and fiscal representation, is now thought to be key in promoting equitable and resilient development (Wilkinson et al., 2014).

Local organisations and groups perform a variety of functions to manage risk, which have been broadly classified into the following: information gathering and dissemination, resource mobilisation and allocation; skills development and capacity building; providing leadership; liaising with other institutions and decision makers (Agrawal, 2008); as well as law enforcement and conflict resolution (Eriksen \& Lind, 2009). The degree 
to which any one organisation or group engages (or attempts to engage) in these functions will vary according to its mandate, internal structure, and the resources available.

Notions of risk governance draw heavily on natural resource management and common property regimes literature (see for example Brockhaus, Djoudi, \& Kambire, 2012; Frankenberger, Spangler, Nelson, \& Langworthy, 2012; Ostrom, 1990; Plummer \& Armitage, 2007). Risk governance describes how collective action decisions are taken to manage risk, where emphasis is placed on the characteristics of-and relationships betweeninstitutions and the modes of decision making; but it can also be used in a normative sense to refer to the desirable qualities of a system, such as adaptiveness and selfregulation (Biermann, 2007; Biermann et al., 2009; PahlWostl, 2009; Stoker, 1998). At various times and within various (sub) disciplines, these positive governance characteristics have been collectively given designations such as 'new governance' (Lockwood, Davidson, Hockings, Haward, \& Kriwoken, 2012), 'adaptive co-management' (Jerneck \& Olsson, 2008). More recently, the concept of 'transformation' places questions of governance and policy at the centre of efforts to foster (or overcome barriers to) the resilience of livelihood systems (Tanner et al., 2015). Carabine, Venton, Tanner and Bahadur (2015) identify five characteristics of risk governance systems that are believed to be important for building resilience, derived from the social-ecological resilience literature (as reviewed recently by Biggs, Schlueter and Schoon, 2015). These are: 1) diversity, 2) polycentricism and connectivity, 3) decentralisation and flexibility, 4) participation and community engagement, and 5) learning and innovation.

Most donor-funded resilience programmes today provide different types of services to help households and communities build the assets and skills that will help them anticipate, absorb and adapt to shocks and stresses (Bahadur et al., 2015). In particular, the provision of ecosystem, climate and financial services is popular in resilience programming (Haworth, Frandon-Martinez, Fayolle, \& Simonet, 2016; Jones, Harvey, \& Godfrey-Wood, 2016). Little is known however about the way local risk governance systems and the broader institutional arrangements in which they are embedded, mediate people's access to these services and therefore result in improved resilience. Understanding how governance structures shape the resilience of households and communities is key to the success of resilience building programmes that are delivered at the community level and also those that attempt to scale up interventions and replicate at a wider scale.

This paper responds to an identified need to better understand the role of local governance systems in building resilience, by answering the following questions:

- How do the services provided through resilience programmes help households and communities to build the assets that make them more resilient to climate shocks and stresses?

- How do governance arrangements mediate access to these services?

A normative approach to the question of risk governance and resilience suggests that the system characteristics of diversity, polycentrism, decentralisation, participation, learning and innovation would be more supportive of-and facilitate-people's access to resilience services (than more centralised, authoritarian systems using fewer types of knowledge and with information flowing in only one direction). Yet it is not clear how they do for these very different kinds of services, or if some of these characteristics are more important than others. In particular, we are interested in whether risk governance systems made up of multiple types of knowledge and institutions (diversity) strengthen management of ecosystem, financial and climate services, and if so, how power dynamics at different scales (polycentricism and connectivity) mediate access to these services for different groups within communities.

The following sections strive to answer these questions. First, we outline the theoretical perspectives on how ecosystem, financial and climate services contribute to building household assets and strengthening resilience. Second, we explore institutional arrangements for risk management of poor and vulnerable communities. The examples provided here focus on the Sahel and Horn of Africa; areas facing significant and increasing climate risk (IPCC, 2014) and where there is an identified need to scale up resilience interventions beyond the community level and engage with governance systems.

\section{Social-Ecological Systems Theory for Resilient Risk Governance: A Conceptual Framework}

The conceptual approach outlined below draws on socialecological resilience theory to propose a set of connections between risk governance, access to assets that help strengthen resilience, and some of the anticipated resilience outcomes at household and community levels (Carabine et al., 2015) (see Figure 1).

\subsection{Resilience Characteristics}

Social-ecological resilience theory recognises that complex and dynamic interactions occur within and between scales (Cumming, Cumming, \& Redman, 2006; Gunderson \& Holling, 2002). Collective decisions on how to manage risk are the outcome of complex interactions between firmly embedded social structures and the choices and individuals. The growing interconnectedness between global and local scales makes it even more challenging to understand how system level, overarching processes interact with adaptive behaviour and agency at the local level (Adger et al., 2009; Wilbanks, 2007). This section outlines several well-established principles-or 


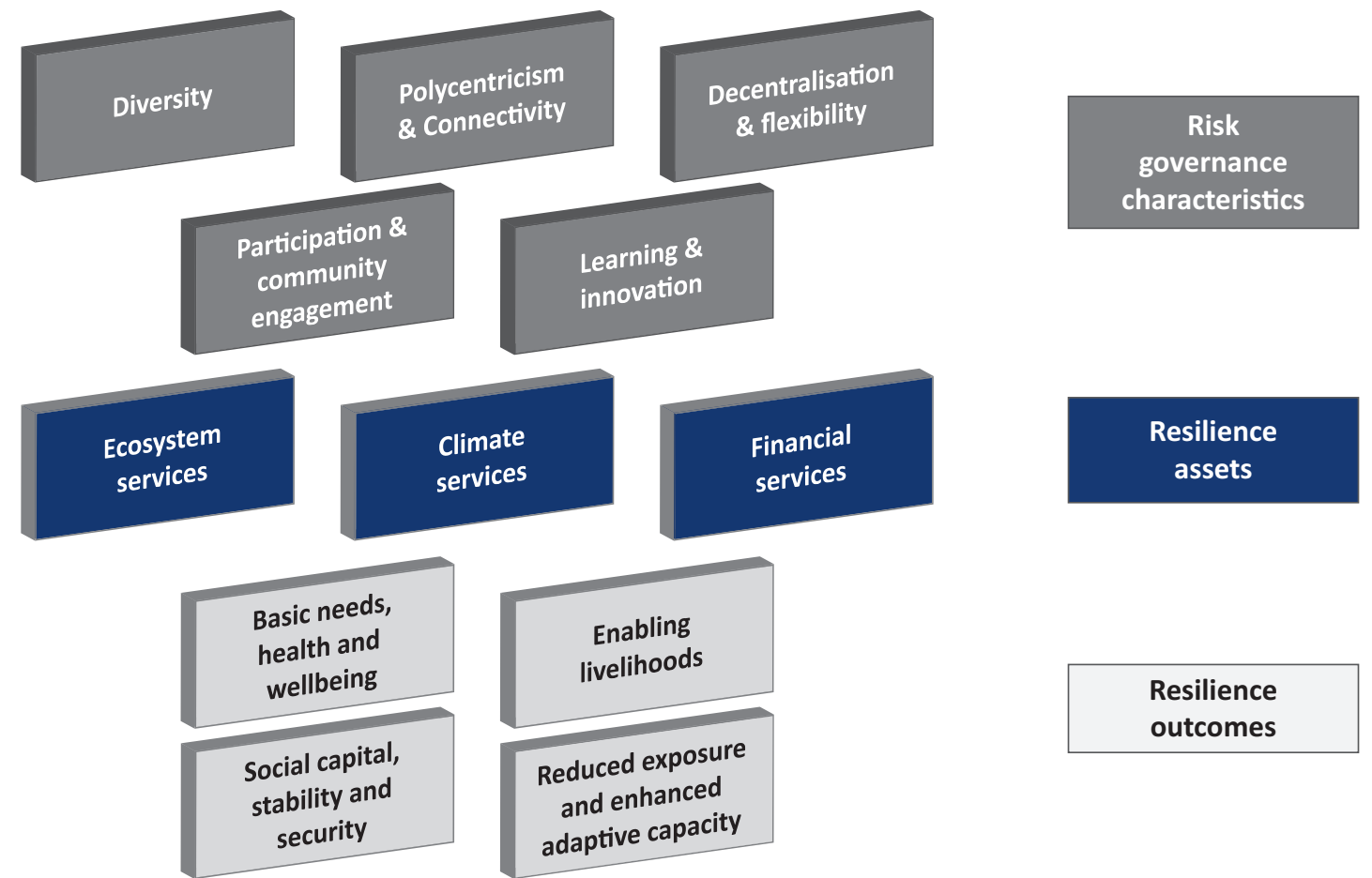

Figure 1. Conceptual framework linking risk governance characteristics with resilience outcomes.

desirable characteristics of-institutions for local-level risk management based on social-ecological systems theory (Biggs et al., 2015).

\subsubsection{Diversity}

Inclusion of a diverse range of actors and institutions in risk management, both informal and formal, will generate a diversity of responses (Renn et al., 2011; Robinson \& Berkes, 2011). In particular, the inclusion of different knowledge systems and blending of scientific and indigenous knowledge is encouraged (Agrawal, 1995).

\subsubsection{Polycentricism and Connectivity}

The structure of the governance system should be such that the diversity of actors can organise themselves and there be multi-level interactions across administrative boundaries and vertical integration (Pahl-Wostl, 2009). This polycentricism in institutional arrangements (i.e., multiple sources of decision making) is needed to address complex problems (Biggs et al., 2015; Osbahr, Twyman, Adger, \& Thomas, 2010). Similarly, in a risk governance system connections between institutions across scales is thought to improve communities' resilience to shocks and stresses (Twigg et al., 2013), by helping to ensure resources and information are channelled to the local level effectively (Nelson, Adger, \& Brown, 2007) and lessons from local level risk management can inform higher level policies (Wilkinson, 2013). At the same time, it is recognised that risk governance at one particular level can also be affected by cross-scalar dynamics be- tween levels of decision making (Walker, Holling, Carpenter, \& Kinzig, 2004).

\subsubsection{Decentralisation and Flexibility}

The decentralisation of decision-making and fiscal responsibility to manage risk to the local level can promote approaches that are more appropriate to the local context (Biggs et al., 2015; Wilkinson, 2012). In principle, a local risk governance system should have the flexibility to make decisions regarding planning and service delivery and change course in response to local conditions (Nelson et al., 2007). In practice however, decentralising decision making to the lowest level may not be more sustainable or equitable unless there are mechanisms in place to promote financial responsibility and political accountability (Ribot, 2002).

\subsubsection{Participation and Community Engagement}

The importance of community engagement and participation in the management of natural resources and risk are well recognised in the resilience literature (Biggs et al., 2015; Manyena, 2006; Nelson et al., 2007). Building in processes for meaningful engagement can help foster ownership, ensure solutions are focused on local needs and are sustainable (Wilkinson, 2012).

\subsubsection{Learning and Innovation}

Given the complex dynamics of socio-ecological systems and their interaction with a changing climate, iterative 
learning processes are needed as well as management plans that are explicitly designed to evolve as new information becomes available (Morgan et al., 2009; National Research Council [NRC], 2009). Continual learning and innovation are valuable processes to enhance institutional memory and avoid mistakes being repeated (Gunderson \& Holling, 2002).

\subsection{Methodology}

The review methodology employed was designed to assess the evidence on how governance is shaping the provision of services, how these are accessed and whether they can contribute to resilience outcomes. This review focuses on the Horn of Africa and Sahel where resilience programmes have been implemented and where the three kinds of services are being delivered and accessed.

Without attempting a full systematic review, the methodology employed is nevertheless employed to achieve rigour, transparency and objectivity (Collins, Miller, Coughlin, \& Kirk, 2015; Haddaway, Woodcock, Macura, \& Collins, 2015). This approach has been designed specifically to manage the realities of the 'information architecture' found within the field of humanitarian and development programming, which includes the grey literature as well as journals (Hagen-Zanker \& Mallett, 2013). Thus, literature searches of both peer reviewed journal articles and relevant grey literature were conducted, using Scopus, Web of Science Core Collections, Eldis and Google Scholar. In the first instance, a review of key theoretical papers was used to aid the identification of key words and phrases, along with their variants and synonyms, which formed the basis of search strings and inclusion/exclusion criteria.

The literature search yielded significantly more evidence on how governance systems shape the delivery and use of ecosystem services. There are relatively few studies on how climate services are delivered, as these are relatively new. Similarly, the literature linking financial services with resilience and risk governance is relatively nascent.

\section{Governance for Access to Resilience Assets: Experience from the Sahel and Horn of Africa}

A review of the literature offers numerous examples -ranging from broad descriptors to highly contextual examples-of how ecosystem services, financial services and climate forecasting can foster adaptive capacity, through the diversification of livelihood activities and strategies (including both agricultural and nonagricultural activities), by building livelihood assets and incomes, and informing long-term planning, among others (see for example Frankenberger et al., 2012). These kinds of changes, collectively referred to here as 'resilience outcomes', are linked in different ways to the provision, access and use of ecosystem, financial and climate services. This section reviews the hypotheses for how these sets of assets-ecosystem services, financial services and climate services-can contribute to resilience and what the literature tells us about the role of good governance in delivering these assets, with a particular focus on the Sahel and Horn of Africa regions.

\subsection{Ecosystem Services}

Globally, rural livelihoods rely heavily on provisioning, regulating and cultural ecosystem services. Ultimately, ecosystem services also provide many of the basic livelihood assets that provide overall health and well-being, including water, fuel, food and fiber, the availability of which, under normal conditions, can help to strengthen household and community resilience in periods of stress and shock (Carabine et al., 2015). The relative importance of various specific ecosystem services may vary within and between communities. For example, pastoralists inhabiting arid and semi-arid lands in Africa and Asia practice transhumance (moving livestock from one grazing ground to another in a seasonal cycle) as a strategy to exploit spatial variation ecosystem services. These include rainfall patterns, the natural regulation of ground and surface water and the inherent regenerative capacity of savanna and forest ecosystems to help ensure that a diversity of resources are available to help withstand shocks ranging from severe and prolonged drought, to long-term land degradation and political upheaval (Frankenberger et al., 2012; Hesse, Anderson, Cotula, Skinner, \& Toulmin, 2013; Robinson \& Berkes, 2011).

More settled populations depend upon the availability of wild edible plants and other non-timber forest products, as well as the provision of primary inputs for alternative livelihood activities, such as timber and charcoal production; fishing and hunting (Shumsky, Hickey, Johns, Pelletier, \& Galaty, 2014); and cultivating a diversity of crops (Folke et al., 2004). For example, in Ethiopia, forested areas provide wild edible plants and other subsistence food-stuffs, which are particularly valuable during droughts and other periods of hardship. Marketable commodities including frankincense, myrrh, gum arabic and henna offer opportunities for alternative sources of income and the diversification of livelihood activities. Across four districts of Ethiopia, community forestry management has been mainstreamed, with initial results showing promise for achieving sustainable management of ecosystem services like non-timber forest products and the more equitable distribution of their benefits (Flintan et al., 2013). Managing diverse ranges of ecosystem services enables people to pursue alternative income-generating and livelihood strategies during periods of shock or stress, such as adverse weather conditions (Carabine et al., 2015).

For many years, practical support to build resilience in the Sahel and Horn of Africa has aimed to establish community-based natural resource management systems and foster sustainable and equitable governance of common pool resources. This experience has led re- 
searchers, development practitioners, policymakers and others to appreciate the influence governance structures have in mediating the development and provision of those assets and services that underpin such initiatives.

Given the climate-sensitive nature of many livelihood assets such as pastures, water resources, coastal and inland fisheries, forests, and even physical infrastructure such as roads, bridges and irrigation systems, climate change is poised to create a variety of new and qualitatively distinct challenges to rural livelihoods, which local institutions will be central to addressing. To do so, it is crucial that new and more adaptive risk governance structures and institutional arrangements are forged (Agrawal, 2008; Brown \& Sonwa, 2015; Fankhauser, Smith, \& Tol, 1999; Sharma, Orindi, Hesse, Pattison, \& Anderson, 2014; Washington-Ottombre \& Pijanowski, 2013).

In many cases, the seeds of such resilient risk governance systems are already present, particularly at the local level. Then the task becomes one of identifying, maintaining, strengthening and better integrating institutions across scales of risk governance. For example, a sizable body of evidence has emerged to suggest that many of the management strategies that pastoralists in the Sahel and Horn of Africa regions of Africa employ-including the maintenance of traditional governance structures and various informal institutions-are not merely coping strategies, but strategies for managing risk through the optimisation of resources (Flintan et al., 2013; Hesse \& MacGregor, 2006; Krätli \& Schareika, 2010; Little, McPeak, Barrett, \& Kristjanson, 2008). Effective drought risk management should incorporate such customary, local-level institutions and other natural resource management authorities (Hesse \& Macgregor, 2006), as well as informal institutions such as transhumance, herd-splitting, social and familial networks of livestock 'loaning' and customary property rights regimes (Flintan et al., 2013).

However, the authority and efficacy of these customary institutions have been eroded considerably in recent decades, in part due to policy decisions and development interventions, as well as changing economic, climatic and security conditions (Helland, 2000; Vedeld, 1994). Continuing the previous example, a proliferation of government- and donor-funded wells and boreholes in semi-arid regions of Kenya, Somalia and Ethiopia coupled with point-source provision of health care, veterinary services, education, emergency food aid and other social protection services, have had significant effects on the pastoralist institutions described above. In turn, this has contributed to negative environmental effects as a result of over-stocking and unsustainable rates of groundwater exploitation, which relate directly with greater sedentarisation and population density (Gomes, 2006; Little et al., 2008). In these cases, the critical role of informal institutions in managing access to resources has been eroded, effectively reducing the resilience of pastoralist communities.
Some sub-Saharan African countries have undergone decentralisation of risk-and natural resourcemanagement functions in recent years with equivocal outcomes for access to ecosystem services. Senegal's Rural Community Councils and Sub-prefects, Zimbabwe's Rural District Councils, and analogous entities elsewhere have assumed authority for a variety of tasks key to disaster risk reduction, natural resource management and the provision of resilience-linked services. But often, these institutions are without adequate support for greater inclusiveness, accountability or democratisation, not to mention financial and technical capacity (Manyena, 2006). Frequently, the effects are such as to undermine customary institutions and governance structures without effectively replacing them. In this way, the failure to adequately integrate formal public and civil sector institutions with informal and customary institutions may actually reduce the diversity of possible responses rather than increase available options (Leslie \& McCabe, 2013).

Despite these challenges, innovative governance structures have been developed and piloted to fill these gaps and to create more effective, decentralised and participatory approaches to the management of climate sensitive and resilience-linked livelihood assets. One promising example is the Local Conventions approach being instituted in a number of Sahelian West African states. This approach begins with a natural resource assessment, followed by participatory community deliberation on rights of use and access, and concludes with a formalised agreement among all involved stakeholders. This approach has proved particularly effective in helping to avoid and manage conflict over resources in areas marked by a diversity of livelihood strategies (Roe, Nelson, \& Sandbrook, 2009). Another similar strategy, known as the Rural Code, has been developed in Niger. This legal framework grants collective grazing and water access rights to herders in their home areas, while granting the communities authority to negotiate usage rights with other groups. This approach provides both a framework and an incentive for the empowerment of customary governing bodies, effective decentralisation and a clear path toward the equitable provision of important livelihood assets among different stakeholders (Roe et al., 2009). In light of these challenges and opportunities, a number of academics, nongovernmental organisations and policymakers are calling for greater support for local governments, customary institutions and governance innovations as well as greater integration among institutions and across scales (Flintan et al., 2013).

To increase participation of communities in risk governance, Shared Learning Dialogues were established in Isiolo, in northern Kenya, which included stakeholders from the local pastoralist and agro-pastoralist communities along with government agencies and local civil society organisations. These platforms functioned as fora to both disseminate and deliberate on climate forecasts from the Kenya Meteorological Department, as well as to collectively prioritise adaptation activities and mobilise 
community resources to implement them (Hesse \& Pattison, 2013). The Shared Learning Dialogues led to efforts towards deliberately structuring natural resource management institutions that were more diverse, participatory, deliberative, decentralised, and integrated with other relevant agencies and institutions. A similar approach, with equally encouraging results, is reported by CARE (2012) from the neighbouring province of Garissa in Kenya. However, another initiative, known as the focal area approach, encountered a number of challenges when implemented in that same location. This was reportedly due to a failure to adequately integrate the relevant private, public and civil society institutions, along with limited technical capacity on the part of some participating extension personnel, severely constraining the effort's potential impact (Kiara, 2011). While highlighting some of the potential challenges to implementing meaningful governance reform in service of resilience building, these examples do lend further evidence to the importance of these resilience characteristics.

\subsection{Financial Services}

Financial services, and in particular credit, offer opportunities for livelihood strengthening and diversification extending into small-scale manufacturing, trade, the service sector and other activities (Good Governance Learning Network [GGLN], 2014), in addition to the ability to invest in new or expanded agricultural assets like fertilisers, hired labour, veterinary services, machinery and crop protection products (Madajewicz, Tsegay, \& Norton, 2013). Microfinance organisations, particularly savings driven community-based organisations, have also been shown to serve as excellent forums for developing and refining skills such as household budgeting and financial planning, business management, and other aptitudes that can catalyse long-term adaptive planning (GGLN, 2014).

Increased household savings, particularly when coupled with budgeting and financial planning, can make an important contribution to preparedness, not only in the case of unanticipated covariate shocks, such as droughts, floods and conflict, but also with regards to predictable fluctuations in income and expenditure, including seasonally-recurring events (e.g. the "hunger months' just before harvest or annual school fees) as well as idiosyncratic shocks (e.g., a wedding, illness or injury) (GGLN, 2014).

Evidence of the potential contribution of financial services-including savings, credit, insurance and training in financial literacy-to household and community resilience is convincing (Hallegatte et al., 2016; Haworth et al., 2016). Research on externally supported microcredit schemes has demonstrated that the availability of credit can play a pronounced role in helping women and children avoid acute food insecurity and malnutrition in the immediate aftermath of a shock (Doocy, Teferra, Norell, $\&$ Burnham, 2005) while reducing the risk of long-term household asset erosion and chronic poverty following disasters (Carter, Little, Mogues, \& Negatu, 2004). Even more innovative financial instruments, such as integrated weather-based index insurance programmes, have shown significant potential for minimising losses and accelerating recovery after climate-related shocks, especially drought (Madajewicz et al., 2013).

Across countries, fiscal decentralisation appears to be a vital component for communities to be able to manage and access resilience assets (Manyena, 2006). However, some governments remain hesitant to devolve fiscal authorities to local communities, noting that administration and oversight of so many small grants is in itself often impractical. In Kenya, the jointly funded Arid Lands Resource Management Project (ALRMP)-which provided technical support, early warning systems and coordinated response strategies across multiple scalesproved effective in significantly mitigating the damage to the country's pastoralist communities. Complementing these governmental programmes are a variety of participatory climate information services and community-led adaptive planning efforts led by various international research and development organisations.

The institutions that govern the provision of financial services, regardless of whether emerging within communities or initiated by external actors, appear to play a vital role in ensuring households possess the resources necessary to withstand unanticipated shocks. They can also help generate social capital and networks, providing complementary benefits (Brown \& Sonwa, 2015; Caretta, 2014; GGLN, 2014). How financial services are designed has a significant influence on the extent to which that potential can be reached, and there are numerous examples of microfinance organisations failing, either in part or in full, to achieve their stated objectives (see, for example, Carter, de Janvry, Sadoulet, \& Sarris, 2015, and Yaro et al., 2015). Interestingly, many of the design principles employed by the highly successful South African microfinance initiative led by SaveAct, as described in GGLN (2014), correspond closely with the principles of effective governance of common pool resources advocated by Ostrom (1990), Agrawal (2008), and others. These include: having clearly defined membership consisting of those with a history of successful collaborative experiences (i.e., savings groups are self-selecting); having rules that are simple and easy to understand, with clear mechanisms for enforcement; and the availability of low cost adjudication (i.e. savings groups draft their own bylaws, including means of adjudication and sanction).

\subsection{Climate Services}

Climate services provide community members with localised, probabilistic weather forecasts-sometimes in conjunction with, or incorporating, traditional and ecological approaches to agro-meteorology-helping farmers, pastoralists and other end-users to make informed risk management decisions, reducing their vulnerability 
to climate related shocks (CARE, 2012; Kgakatsi \& Rautenbach, 2014). Most success in Africa and Asia has been observed in improved forecasting and use of seasonal weather information (Wilkinson et al., 2015).

Medium- and long-term climate forecast data can also serve a variety of functions at local, state/provincial and national levels, including informing decisions around land-use planning, infrastructure investments and urban development, coastal management and flood control efforts, and natural resource management and agricultural policy. Collectively, these functions constitute a contribution to strengthening resilience, although significant challenges exist to the meaningful adoption and use of climate information in developing nations (Jones, Carabine, Roux, \& Tanner, 2015). These include the fundamental disconnect between the priorities of producers and end-users of climate forecast data, challenges to effective communication between the two groups and technical issues related to scale and resolution of available information (Jones et al., 2015). Compounding these challenges are a host of technical, financial and institutional constraints that conspire to limit the uptake and effectiveness of medium and long-term climate forecasts in public policy making (Fankhauser et al., 1999; Jones et al., 2015).

The literature on governance and the use of climate services is relatively limited. At the regional level in the Horn of Africa, there is a shift towards greater investment in, and cross-scalar integration of climate services provision and drought early warning systems (Fitzgibbon \& Crosskey, 2013). One example of this trend is the establishment in 2011, of the National Drought Management Authority (NDMA) in Kenya, which has been delegated responsibility for operating Kenya's Early Warning System as well as coordinating district and community-level disaster risk reduction and contingency funding initiatives. A second, though to date less developed, initiative comes from the Ethiopian Disaster Risk ManagementAgricultural Task Force. In terms of regional institutional arrangements, drought risk governance is coordinated under the Inter-Governmental Authority on Development in the Horn of Africa (IGAD) Drought Disaster Resilience and Sustainability Initiative (IDDRSI). Each member state is responsible for embedding this regional initiative into national processes, of which Kenya is the most advanced, launching its Ending Drought Emergencies (EDE) framework in 2015. Institutional development and knowledge management are central to the framework, drawing together a wide range of stakeholders (Carabine et al., 2015). However, across the region climate services remain centrally provided and largely disconnected from local knowledge about the dynamics of weather and seasonality.

\section{Discussion}

Based on the examples provided in the literature for the Sahel and Horn of Africa regions and elsewhere, Table 1 offers a concise, if simplified, representation of the prin- cipal resilience outcomes associated with ecosystem services, climate forecasting services and financial services, particularly in rural regions (where these have been observed) and the resilient governance characteristics most likely to promote these. It is not exhaustive but does suggest that some aspects of risk governance are more strongly connected with particular resilience outcomes. A risk governance system that has all the characteristics represented in the matrix, would therefore strengthen access to a variety of services and produce multiple resilience outcomes.

A significant caveat is warranted here, however, with important implications for the direction of future research and development efforts. Many developing nations face severe limitations in the availability of human, financial and technical resources, which make it necessary to prioritise development initiatives and governance reforms (Herrfahrdt-Pahle, 2013). In other words, it is rarely possible to achieve all of desired risk governance characteristics, in all localities, across all sectors simultaneously. There is a need to further identify and test best practice in terms of how to approach piecemeal governance reform with aims to contain costs, maximise synergies and avoid contradictions.

A further complication is the reality that risk governance characteristics may themselves be subject to threshold effects. An example would be the case when greater community participation did not provide a proportionally greater contribution to resilience, with no observable benefit at all prior to the achievement of some minimum effective level of community engagement (Cornwall, 2008). However, much more needs to be learned considering the significant impacts such conditions would have on the design and implementation of initiatives targeted at improving resilience (Young, 2010).

Finally, Table 1 is intended to capture the principal relationships between governance characteristics and community resilience (via access to key services), but the level of importance or specific impacts of different risk governance characteristics is likely to vary significantly according to the locality in question, and depending on the types of livelihood activities communities are engaged in. In interpreting this table, it is interesting to note that the governance of ecosystem services is seemingly more closely linked to livelihood outcomes, whereas financial and climate services also have the potential to help communities reduce exposure and enhance adaptive capacity. Enhanced social capital to deal with shocks and stresses appears to be mostly associated with financial and climate services if there are strong processes of learning and innovation in their provision.

All of these gaps point to the need for further research that might eventually guide the creation of a decision support tool or tools capable of offering practical guidance on programming on governance reform for improved resilience in light of the diversity of real-world development contexts encountered. In doing so, it will be possible to better identify the entry points for improved 
Table 1. Matrix of resilience outcomes associated with different risk governance regimes.

\begin{tabular}{llll}
\hline & Ecosystem Services & Financial Services & Climate Services \\
\hline Diversity & A, B, D & B, D & A \\
Polycentricism and Connectivity & A, B & A, D & A, D \\
Decentralisation and Flexibility & A, B, C & A, B, D & B, D \\
Participation and Community Engagement & A, B, C & A, B, D & B, D \\
Learning and Innovation & C & C & C
\end{tabular}

\section{Key to resilience outcomes:}

$A=$ Basic needs, health and well-being

$\mathrm{B}=$ Enabling livelihoods

C = Social capital, stability and security

$\mathrm{D}=$ Reduced exposure and enhanced adaptive capacity

risk management and where the thresholds lie in terms of local risk governance.

\section{Conclusions}

There is a growing literature documenting experiences around how ecosystem, financial and climate services can strengthen resilience at the local level. There is less evidence regarding the importance of governance systems in mediating access to these assets. Most examples can be found in the field of natural resource management, where there is a longer history of interventions aimed at building resilience relative to financial or climate services. The evidence indicates that these services are delivered in different ways through different institutional arrangements with implications for the way in which people access them.

Ecosystem services are often delivered at the local level and governed by complex institutional arrangements with actors, including governments, non-governmental organisations and community-based organisations, that often overlap. With such complex institutional arrangements, the risk governance characteristics discussed in this paper may help to identify routes towards more resilient risk governance at the community level.

In many cases, climate services are delivered by national governments, often bypassing local governance structures. Therefore, while access to, use and application of weather and climate information and services in Africa and elsewhere are increasing, end-users continue to face challenges in receiving and applying these services. Greater integration between the national, scientific institutions that produce climate and weather information, with the local, informal institutions, which are more easily accessed, appears therefore to be critical to building resilience. Polycentricism and diversity of institutions, as principles of risk governance, would seem to be particularly important for the delivery of climate services in resilience programmes.

In many areas of the Sahel and Horn of Africa, the formal financial sector is largely absent. In these cases financial services are often provided informally, by women's savings groups or through reciprocity within social groups. Increasingly, non-governmental organisations are delivering financial services, via Village Savings and Loan Associations for example, and private sector actors are also moving into this service area, delivering microfinance and insurance products in places that are vulnerable to climate change and extreme weather events. In assessing the implications for community resilience of these shifting institutional arrangements, it will be important to consider the role these actors can play in wider risk governance systems.

The literature on resilience is rapidly expanding beyond concepts and theory into areas of practice, looking at the various roles that services play in strengthening people's capacities to anticipate and adapt in the face of shocks and stresses. Limited attention has been paid however, to the institutions governing how households and communities access and use these services. The socio-ecological resilience literature suggests that some risk governance systems will be more effective than others in reaching the most vulnerable. In this paper we have indicated a way forward for researchers and practitioners to test these hypotheses and build a greater body of evidence on the role of risk governance in delivering resilience outcomes.

\section{Acknowledgements}

Sabrina Chesterman provided vital contributions to earlier drafts of this paper. The authors acknowledge funding received from the Building Resilience and Adaptation to Climate Extreme Disasters (BRACED) programme of the Department for International Development and the Overseas Development Institute's Research and Innovation Fund.

\section{Conflict of Interests}

The authors declare no conflict of interests.

\section{References}

Adger, W. N., Dessai, S., Goulden, M., Hulme, M., Lorenzoni, I., Nelson, D. R., ... Wreford, A. (2009). Are there 
social limits to adaptation to climate change? Climatic Change, 93(3), 335-354. doi:10.1007/s10584008-9520-z

Agrawal, A. (1995). Dismantling the divide between Indigenous and scientific knowledge. Development and Change, 26(3), 413-439. doi:10.1111/j.14677660.1995.tb00560.x

Agrawal, A. (2008). The role of local institutions in adaptation to climate change. Washington, DC: World Bank.

Bahadur, A., Peters, K., Wilkinson, E., Pichon, F., Gray, K. \& Tanner, T. (2015). The 3As: Tracking resilience across BRACED. London: ODI.

Biermann, F. (2007). "Earth system governance" as a crosscutting theme of global change research. Global Environmental Change: Human and Policy Dimensions, 17, 326-337.

Biermann, F., Betsill, M. M., Gupta, J., Kanie, L., Lebel, L., Liverman, D., .. . Siebenhuener, B. (2009). Earth system governance: People, places and the planet. Science and Implementation Plan of the Earth System Governance Project. Bonn: The Earth System Governance Project.

Biggs, R., Schlueter, M., \& Schoon, M. L. (2015). Principles for building resilience: Sustainaing ecosystem services in social-ecological systems. Cambridge: Cambridge University Press.

Britton, N. (2001). A new emergency management for the new millennium? Australian Journal of Emergency Management, 16(4), 44-54.

Brockhaus, M., Djoudi, H., \& Kambire, H. (2012). Multilevel governance and adaptive capacity in West Africa. International Journal of the Commons, 6(2), 200-232.

Brown, H. C. P., \& Sonwa, D. J. (2015). Rural local institutions and climate change adaptation in forest communities in Cameroon. Ecology and Society, 20(2). doi:10.5751/ES-07327-200206

Carabine, E., Venton, C. C., Tanner, T., \& Bahadur, A. (2015). The contribution of ecosystem services to human resilience: A rapid review. London: ODI. Retrieved from https://www.odi.org/sites/odi.org.uk/ files/odi-assets/publications-opinion-files/9394.pdf

CARE. (2012). Decision-making for climate resilient livelihoods and risk reduction: A participatory scenario planning approach. Retrieved from http:// www.careclimatechange.org/files/adaptation/ALP_P SP_Brief.pdf

Caretta, M. A. (2014). "Credit plus" microcredit schemes: A key to women's adaptive capacity. Climate and Development, 6(2), 179-184. doi:10.1080/17565529. 2014.886990

Carter, M. R., de Janvry, A., Sadoulet, E., \& Sarris, A. (2015). Index-based weather insurance for developing countries: A review of evidence and propositions for scaling-up (FERDI Working Paper no. 112). Clermont-Ferrand: FERDI.

Carter, M. R., Little, P. D., Mogues, T., \& Negatu, W. (2004). Shock, sensitivity and resilience: Tracking the economic impacts of environmental disaster on assets in Ethiopia and Honduras. International Food Policy Research Institute. Retrieved from http://www.ifpri.org/publication/shocks-sensitivityand-resilience-0

Collins, A., Miller, J., Coughlin, D., \& Kirk, S. (2015). The production of quick scoping reviews and rapid evidence assessments: $A$ how to guide. Retrieved from https://www.gov.uk/government/uploads/system/ uploads/attachment_data/file/560521/Production_ of_quick_scoping_reviews_and_rapid_evidence_ass essments.pdf

Cornwall, A. (2008). Unpacking "participation": Models, meanings and practices. Community Development Journal, 43(3), 269-283.

Cumming, G. S., Cumming, D. H. M., \& Redman, C. L. (2006). Scale mismatches in social-ecological systems: Causes, consequences, and solutions. Ecology And Society, 11(1). Retrieved from file://C:/Users/ Rodrigo\%200\%20Grande/Downloads/ES-2005-1569 .pdf

Doocy, S., Teferra, S., Norell, D., \& Burnham, G. (2005). Credit program outcomes: Coping capacity and nutritional status in the food insecure context of Ethiopia. Social Science \& Medicine, 60(10), 23712382. doi:10.1016/j.socscimed.2004.10.025

Eriksen, S., \& Lind, J. (2009). Adaptation as a political process: Adjusting to drought and conflict in Kenya's drylands. Environmental Management, 43(5), 817-835. doi:10.1007/s00267-008-9189-0

Fankhauser, S., Smith, J. B., \& Tol, R. S. J. (1999). Weathering climate change: Some simple rules to guide adaptation decisions. Ecological Economics, 30(1), 67-78. doi:10.1016/S0921-8009(98)00117-7

Fitzgibbon, C., \& Crosskey, A. (2013). Disaster risk reduction management in the drylands in the Horn of Africa. Retrieved from https://cgspace.cgiar.org/bitstream/ /handle/10568/27614/tc_brief4.pdf?sequence=2

Flintan, F., Behnke, R., \& Neely, C. (2013). Natural resource management in the drylands in the Horn of Africa. Nairobi: ILRI. Retrieved from https://cgspace. cgiar.org/handle/10568/27611

Folke, C., Carpenter, S., Walker, B., Scheffer, M., Elmqvist, T., Gunderson, L., \& Holling, C. S. (2004). Regime shifts, resilience, and biodiversity in ecosystem management. Annual Review of Ecology, Evolution and Systematics, 35, 557-581.

Frankenberger, T. R., Spangler, T., Nelson, S., \& Langworthy, M. (2012). Enhancing resilience to food insecurity amid protracted crisis. Rome: FAO. Retrieved from http://www.fao.org/fileadmin/templates/cfs_high_I evel_forum/documents/Enhancing_Resilience_Food Insecurity-TANGO.pdf

Good Governance Learning Network. (2014). Community resilience and vulnerability in South Africa: Perspectives from civil society on local governance in South Africa. Retrieved from ggln.org.za/1solg-publication2014.pdf 
Gomes, N. (2006). Access to water, pastoral resource management and pastoralists' livelihoods: Lessons learned from water development in selected areas of Eastern Africa (LSP Working Paper 26). Rome: FAO

Haddaway, N. R., Woodcock, P., Macura, B., \& Collins, A. (2015). Making literature reviews more reliable through application of lessons from systematic reviews. Conservation Biology, 29(6), 1596-1605.

Hagen-Zanker, J., \& Mallett, R. (2013). How to do a rigorous, evidence-focused literature review in international development: A guidance note (Working Paper). London: ODI.

Hallegatte, S., Bangalore, M., Bonzanigo, L., Fay, M., Kane, T., Narloch, U., . . . Vogt-Schlib, A. (2016). Shock waves: Managing the impacts of climate change on poverty. Washington, DC: International Bank for Reconstruction and Development. doi:10.1596/978-14648-0673-5

Haworth, A., Frandon-Martinez, C., Fayolle, V., \& Simonet, C. (2016). Climate resilience and financial services. Retrieved from http://www.odi.org/sites/odi. org.uk/files/odi-assets/publications-opinion-files/10 316.pdf

Helland, J. (2000). Institutional erosion in the drylands: The case of the Borana pastoralists. Pastoralists and environment: Experience from the Greater Horn of Africa. Addis Ababa: OSSREA.

Herrfahrdt-Pahle, E. (2013). Integrated and adaptive governance of water resources: The case of South Africa. Regional Environmental Change, 13(3), 551561. doi:10.1007/s10113-012-0322-5

Hesse, B. C., Anderson, S., Cotula, L., Skinner, J., \& Toulmin, C. (2013). Building climate resilience in the Sahel. Proceedings of a Joint FAO/OECD Workshop 2324 April 2012. Rome: FAO. Retrieved from http:// pubs.iied.org/pdfs/G03650.pdf

Hesse, C., \& Macgregor, J. (2006). Pastoralism: drylands' invisible asset? Developing a framework for assessing the value of pastoralism in East Africa (Drylands Issue Paper 142). London: IIED.

Hesse, C., \& Pattison, J. (2013). Ensuring devolution supports adaptation and climate resilient growth in Kenya. London: IIED.

Intergovernmental Panel on Climate Change. (2014). Climate change 2014: Impacts, adaptation, and vulnerability (Working Group II to the Fifth Assessment Report of the Intergovernmental Panel on Climate Change). Retrieved from http://ipcc-wg2.gov/ AR5/images/uploads/WG2AR5_SPM_FINAL.pdf

Jerneck, A., \& Olsson, L. (2008). Adaptation and the poor: Development, resilience and transition. Climate Policy, 8(2), 170-182. doi:10.3763/cpol.2007.0434

Jones, L., Carabine, E., Roux, J.-P., \& Tanner, T. (2015). Promoting the use of climate information to achieve long-term development objectives in sub-Saharan Africa: Results from the future climate for Africa scoping phase. American Journal of Infection Control, 43(2). doi:10.1016/S0196-6553(14)01403-5
Jones, L., Harvey, B., \& Godfrey-Wood, R. (2016). The changing role of NGOs in supporting climate services (BRACED Resilience Intel No. 4). London: ODI. Retrieved from https://www.odi.org/sites/odi.org.uk/ files/resource-documents/10885.pdf

Kgakatsi, I. B., \& Rautenbach, C. J. deW. (2014). The contribution of seasonal climate forecasts to the management of agricultural disaster-risk in South Africa. International Journal of Disaster Risk Reduction, 8, 100-113. doi:10.1016/j.ijdrr.2014.01.002

Kiara, J. K. (2011). Focal area approach: A participatory community planning approach to agricultural extension and market development in Kenya. International Journal of Agricultural Sustainability, 9(1), 248-257. doi:10.3763/ijas.2010.0566

Krätli, S., \& Schareika, N. (2010). Living off uncertainty: The intelligent animal production of dryland pastoralists. The European Journal of Development Research, 22(5), 605-622. doi:10.1057/ejdr.2010.41

Leslie, P., \& McCabe, J. (2013). Response diversity and resilience in social-ecological systems. Current Anthropology, 54(2), 114-143.

Gunderson, L. H., \& Holling, C. S. (2002). Panarchy: Understanding Washington, transformations in human and natural systems. Washington, DC: Island Press.

Little, P. D., McPeak, J., Barrett, C., \& Kristjanson, P. (2008). Challenging orthodoxies: Understanding pastoral poverty in East Africa. Development and Change, 39(4), 585-609. doi:10.1111/j.1467-7660. 2008.00497.x

Lockwood, M., Davidson, J., Hockings, M., Haward, M., \& Kriwoken, L. (2012). Marine biodiversity conservation governance and management: Regime requirements for global environmental change. Ocean \& Coastal Management, 69, 160-172. doi:10.1016/ j.ocecoaman.2012.07.015

Madajewicz, M., Tsegay, A. H., \& Norton, M. (2013). Managing risks to agricultural livelihoods: Impact evaluation of the HARITA program in Tigray, Ethiopia 20092012. Boston: Oxfam.

Manyena, S. B. (2006). The concept of resilience revisited. Disasters, 30(4), 434-450. doi:10.1111/j.03613666.2006.00331.x

Morgan, M. G., Dowlatabadi, H., Henrion, M., Keith, D., Lempert, R. J., McBride, S., . . . Wilbanks, T. (2009). Best practice approaches for characterizing, communicating, and incorporating scientific uncertainty in decision making (Synthesis and Assessment Product 5.2 of the US Climate Change Science Program). Washington, DC: US Climate Change Science Program.

National Research Council. (2009). Informing decisions in a changing climate. Washington, DC: The National Academies Press.

Nelson, D. R., Adger, W. N., \& Brown, K. (2007). Adaptation to environmental change: Contributions of a resilience framework. Annual Review of Environment and Resources, 32(1), 395-419. doi:10.1146/ 
annurev.energy.32.051807.090348

Osbahr, H., Twyman, C., Adger, W. N., \& Thomas, D. S. G. (2010). Evaluating successful livelihood adaptation to climate variability and change in Southern Africa. Ecology and Society, 15(2).

Ostrom, E. (1990). Governing the commons. The Evolution of Institutions for Collective Action, 302. doi:10.1017/CBO9780511807763

Pahl-Wostl, C. (2009). A conceptual framework for analysing adaptive capacity and multi-level learning processes in resource governance regimes. Global Environmental Change, 19, 354-365.

Plummer, R., \& Armitage, D. R. (2007). Charting the new territory of adaptive co-management: A Delphi study. Ecology and Society, 12(2).

Renn, O., Ortleb, J., Benighaus, L., \& Benighaus, C. (2011). Risks Safe or not safe: Deciding what risks to accept in our environment and food. New York, NY: Springer Science.

Ribot, J. (2002). Democratic decentralization of natural resources: Institutionalizing popular participation. Washington, DC: World Resources Institute.

Robinson, L. W., \& Berkes, F. (2011). Multi-level participation for building adaptive capacity: Formal agency-community interactions in northern Kenya. Global Environmental Change, 21(4), 1185-1194. doi:10.1016/j.gloenvcha.2011.07.012

Roe, D., Nelson, F., \& Sandbrook, C. (2009). Community management of natural resources in Africa: Impacts, experiences and future directions. London: IIED.

Sharma, V., Orindi, V., Hesse, C., Pattison, J., \& Anderson, S. (2014). Supporting local climate adaptation planning and implementation through local governance and decentralised finance provision. Development in Practice, 24(4), 579-590. doi:10.1080/ 09614524.2014 .907240

Shumsky, S., Hickey, G. M., Johns, T. C., Pelletier, B., \& Galaty, J. E. (2014). Institutional factors affecting wild edible plant (WEP) harvest and consumption in semi-arid Kenya. Land Use Policy, 38, 48-69. doi:10.1016/j.landusepol.2013.10.014

Stoker, G. (1998). Governance as theory: Five propositions. International Social Science Journal, 50(155), 17-28.

Tanner, T., Lewis, D., Wrathall, D., Bronen, R., CradockHenry, N., Huq, S., . . . Thomalla, F. (2015). Livelihood resilience in the face of climate change. Nature Climate Change, 5(1), 23-26. doi:10.1038/ nclimate2431

Twigg, J., Tanenbaum, J. J. G., Williams, A. M., Desjardins, A., Tanenbaum, K., Peres, E., . . Minshall, T. (2013). An integrated conceptual framework for long-term social-ecological research. International Journal of Production Research. doi:10.1890/100068

van Voorst, R., Wisner, B., Hellman, J., \& Nooteboom, G. (2015). Introduction to the "risky everyday." Disaster Prevention and Management: An International Journal, 24(4). doi:10.1108/DPM-04-2015-0077

Vedeld, T. (1994). The state and rangeland management: Creation and erosion of pastoral institutions in Mali (Drylands Networks Programme Issues Paper no. 46). London: IIED.

Walker, B., Holling, C. S., Carpenter, S. R., \& Kinzig, A. (2004). Resilience, adaptability and transformability in social-ecological systems. Ecology and Society, 9(2), 5.

Washington-Ottombre, C., \& Pijanowski, B. C. (2013). Rural organizations and adaptation to climate change and variability in rural Kenya. Regional Environmental Change, 13(3), 537-550. doi:10.1007/s10113-0120343-0

Wilbanks, T. J. (2007). Scale and sustainability. Climate Policy, 7(4), 278-287. doi:10.1080/14693062. 2007.9685656

Wilkinson, E. (2012). Transforming disaster risk management: A political economy approach. London: ODI.

Wilkinson, E. (2013). Disaster risk governance in volcanic areas (Work Package 4 of the Strengthening Resilience in Volcanic Areas [STREVA] programme). London: ODI.

Wilkinson, E., Budimir, M., Ahmed, A. K., \& Ouma, G. (2015). Climate information and services in BRACED countries (Resilience Intel No. 1). London: ODI. Retrieved from http://www.odi.org/sites/odi. org.uk/files/odi-assets/publications-opinion-files/10 128.pdf

Wilkinson, E., Caravani, A., Canales Trujillo, N., Nakhooda, S., Terpstra, P., \& Peterson Carvalho, A. (2014). Going in the right direction? Tracking adaptation finance at the subnational level. London: ODI.

Young, O. R. (2010). Institutional dynamics: Resilience, vulnerability and adaptation in environmental and resource regimes. Global Environmental Change, 20(3), 378-385. doi:10.1016/j.gloenvcha.2009.10.001

\section{About the Authors}

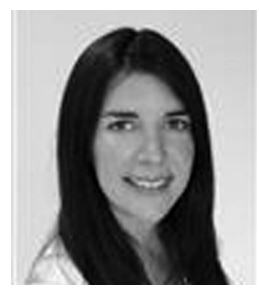

Elizabeth Carabine is a Research Fellow at the ODI. Her research focuses on climate change adaptation, natural resource governance and drought risk management, particularly in the Sahel and Horn of Africa. 


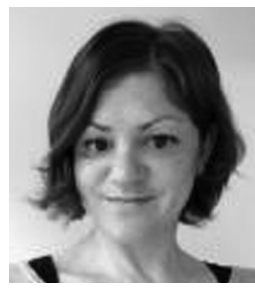

Emily Wilkinson is a Senior Research Fellow at the ODI. Her research focuses on the policy and institutional dimensions of disaster- and climate-risks, including incentives for risk-informed development planning. 